\title{
Retired men and Men's Sheds in Australia
}

Purpose: The purpose of this study is to investigate the influence of charismatic leadership style and value congruence on the social connectedness of retired men in Australian Men's Sheds. This study also explores the impact of social connectedness on well-being outcomes, such as employment and training, improved family relationships and access to health and welfare services.

Design/methodology/approach: The methodology is a qualitative approach using focus groups and semi-structured interviews with Shed leaders and men members.

Findings: Findings suggest that a charismatic leader enhances the value congruence between leaders and their members through empowering, envisioning and empathy, which also contributes to the social connectedness of members and enhances well-being of retired men.

Originality/value: The study provides insights into the factors that contribute to successful leadership, participatory and leadership practices in the Groups/Sheds, and addresses a gap in the literature in the area of leadership and Men’s Sheds.

\section{Introduction}

Men's well-being has become an important social issue, particularly given Australia's ageing population (Australian Bureau of Statistics, 2011). In June 2010, Australians aged 65 years and older represented $13.5 \%$ of the population and that figure is expected to increase to approximately $23 \%$ by 2041 . Even though there is a growing awareness of the need to better prepare for retirement, Golub, Filipowicz and Langer (2002) argue western societies still tend to accept the negative consequences of old age. Further, they argue this complacency will continue to impact on social and health issues for many male retirees unless more attention is paid to life after work.

Little is known about the leadership in the many Men's Group/Sheds across Australia (Arney and Westby, 2012b; Misan, 2008). This research aims to address the existing gap in the current leadership literature through exploring leadership and value congruence in non-profit organisations such as the Men's Shed. The Men's Shed is a community-based organisation that provides a place for work and recreational activities for members throughout Australia (Misan and Sergeant, 2009). The Shed represents a place that bridges the gap between work and retirement and where older men engage in 
social activities and perform meaningful tasks (Ballinger, Talbot and Verrinder, 2009; Glover and Brown, 2006; Morgan, Hayes, Williamson and Ford, 2007; Ormsby, 2010). Men's Sheds were developed in response to issues raised regarding the well-being of retired men (Golding, 2011) and to develop practices to enhance the well-being of men. Labonte and Reid (1997) define well-being as the physical, emotional and social health of an individual and is determined by an individual's abilities and their level of connectedness with others. Ballinger (2009) contends that social connectedness and having a sense of meaning and purpose also contribute to an individual's sense of wellbeing.

This research project investigates the leadership in 60 Men's Sheds in urban and regional areas across all states in Australia. The research explores how leadership style and leader/member value congruence impacts on the level of social connectedness and how the level of social connectedness impacts on well-being outcomes, such as parttime employment and training, improved family relationships and access to health and welfare services of retired men.

The study provides insights into the factors that contribute to successful leadership, participatory and leadership practices in the Groups/Sheds, and addresses a gap in the literature in the area of leadership and Men's Sheds. The research question to be addressed in this study is: How do Men's Group/Shed leaders and leadership practices impact on members and their membership in the Groups/Sheds? The research illuminates the ways men members and Groups/Sheds benefit through effective leadership in these environments. In addressing the research question this study establishes clear links between charismatic leadership, value congruence and social connectedness. The theoretical frameworks used to articulate these constructs include Choi’s (2006) framework on charismatic leadership and McMillian and Charvis (1986) framework on social connectedness.

Charismatic leadership was traditionally viewed as a subset of transformational leadership (Bass, 1985). However, for the purpose of this study we are analysing charismatic leadership in the Men's Shed as a distinct construct as charismatic leadership has not been investigated in the context of the Men's Shed. Charismatic leaders offer a purpose and a challenging vision that aligns follower values and interests with the collective interests of the organisation (Bass, 1985; Jung and Avolio, 2000). 
Value congruence represents the similarity of individual and organisational values (Kristof, 1996). There has been growing interest in the interaction between leaders and their followers (Boehm and Yoels, 2009; Guay, 2013; Hoffman, Bynum and Piccolo, 2011; Huang, Bor-Shiuan and Chou, 2005) as this interaction is linked to positive outcomes such as job satisfaction, organisational commitment, identification, and retention (Kristof-Brown, Zimmerman and Johnson, 2005). Klein and House (1995) and Shamir (1995) also confer that if the followers hold personal values that are compatible with the leader's, the impact of the leader on follower effort and performance is enhanced and the leader's vision is especially powerful.

\section{Origins of the Men's Sheds}

Men's Groups and Sheds are becoming known as one of the largest men's community services in Australia (Cavanagh, McNeil, Bartram and Leggat, 2012). Men's Sheds provide primary health care facilities and services promoting good health and emotional well-being in men (Ballinger, Lyn, Talbot and Verrinder, 2009; Misan, 2008; Ormsby, 2010), including men's clinical services, places for discussions, education, training and work activities (Arney and Westby, 2012a). Men's Sheds provide retired men with the opportunity to socialise and participate in meaningful tasks, both individually and at the community level (Cavanagh, McNeil and Bartram, 2012).

In Australia, there are two main organisations, namely Mensheds Australia (MSA) and the Australian Men's Shed Association (AMSA) that support and promote Men's Sheds. MSA has approximately 280 Groups/Sheds and is a registered health promotion charity that partners with health and other organisations (such as small businesses, local TAFE's, and women's groups) to support Groups and Sheds around Australia. The majority of funding is sourced from the private sector and bequests. Mensheds Australia aims to enhance men's well-being outcomes through projects and sustainable practices. In 2007 the Australian Men's Shed Association (AMSA) was established to support independent Men’s Sheds around this country (Australian Men's Shed Association, 2011). There are now over 1000 Sheds across the country and each Shed is a member of the AMSA (Australian Men's Shed Association, 2011). Men's sheds in community contexts provide an important and voluntary social and community outlet for older retired men (Golding, 2008; Thomson, 2002). 


\section{Leadership and directions for Men's Sheds}

Leadership is about persuading members of a group to strive for a shared goal that is thought to be critical for the responsibilities and welfare of the group. Leadership emerges when members of a group are willing to assume the goals of a specific group as their own for a specific duration (Hogan, Curphy and Hogan, 1994). Charismatic leadership is a distinct type of leadership in which the leader has the capacity to influence and inspire their followers (Conger, Kanungo and Menon, 2000). House and Shamir (1993) define charismatic leadership as an "interaction between leaders and their followers that results in (1) making followers' self-esteem contingent on their involvement in the vision and the mission articulated by the leader, (2) strong internalization of the leaders' values and goals by the followers, (3) strong personal or moral (as opposed to calculative) commitment to these values and goals, and (4) a willingness on the part of followers to transcend their own self-interests for the sake of the collective (team or organisation)” (p. 86). Furthermore, charismatic leadership is a type of leadership that has a profound impact on the emotions of their followers and holds great power over them (Hollander, 1993).

It is uncertain whether the relationships between charismatic leadership and follower behaviour can be generalized to organisations that operate in the non-profit sector. Lord, Brown, Harvey and Hall (2001) and Bryman, Stephens and Campo (1996) suggest leaders in both for-profit and non-profit contexts encounter different challenges and that leadership studies have failed to take into account the context within which leadership research is performed. Thus, they call for more specific context-based research to be conducted in this field. Nevertheless, Australia has a large number of non-profit organisations which make a significant contribution to the society in social, political and economic terms. In fact, the non-profit sector in Australia is the sixth largest in the world, following the Netherlands, Ireland, Belgium, Israel, and the US (Lyons, Hocking, Hems and Salamon, 1999). Despite this, a limited number of articles on leadership have been published about the non-profit sector when compared to the for-profit sector (McMurray, Pirola-Merlo, Sarros and Islam, 2010; Thach and Thompson, 2007).

According to Conger and Kanungo (1988) charismatic leadership can take on two main forms; personalised or socialised. Personalised is exploitative and non- 
egalitarian where socialised is non-exploitative and focuses on position outcomes, such as motivating and satisfying follower needs. The current study will be based on socialised charismatic leadership and will be defined and analysed through three key behavioural components, 1. envisioning, 2. empathy and 3. empowerment. These behavioural components were the focus point in Choi's (2006) study on charismatic leadership and follower motivation and is consistent with traditional studies from Bass (1985), Burke (1986) and Conger (1989).

First, envisioning involves creating a vision for the future that people can identify with and be excited about (Choi, 2006). Charismatic leaders need to be able to formulate the vision in a way that attracts followers with similar values and goals. Communicating the vision is particularly important and charismatic leaders are known for their ability to engage and persuade through personal appeal (Conger, 1989). The charismatic leader inspires their followers to pursue the collective goal by serving as a role model which followers identify with and want to emulate. Furthermore, the charismatic leader instils a sense of strong confidence in their followers' capability to accomplish the vision. (Choi, 2006)

Second, empathy involves being sensitive to follower needs (Bass, 1985). According to Conger and Kanungo (1998) charismatic leaders have a strong tendency to display emotions and sensitivity to their followers' needs. Empathy refers to the capability to comprehend the motives, values and emotions of others. Charismatic leaders are sensitive to the needs and emotions of their followers and followers have a higher propensity to identify with the charismatic leader as this type of leader usually shares followers' feelings. Nevertheless, charismatic leaders encourage the accomplishment of their objectives by taking into account the followers' interests during decision making (Choi, 2006).

Finally, empowerment is closely linked to self-efficacy enhancing one's belief in their skills and capabilities (Bandura, 1977) and as such is a key characteristic of charismatic leadership (Bass, 1985; Burke, 1986; Conger, 1989). Empowerment involves delegation and power sharing with followers as well as fostering a sense of control and becoming more influential at work through a range of managerial interventions. Charismatic leaders intend to encourage their followers to take an active approach to their work roles through empowerment. By doing so, the charismatic leader allows followers to feel influential and competent (Choi, 2006). Charismatic leaders are 
rise out of the group by showing exemplar behaviour and attitudes that are valued by the group.

Previous studies on charismatic leadership have observed that this style produces positive outcomes from the followers such as higher performance and satisfaction (Brown and Trevino, 2009; Conger, Kanungo and Menon, 2000), as well as enhanced emotional and motivational arousal and heightened trust and confidence in the leader (Shamir, House and Arthur, 1993). Similarly, Jung and Avolio (2000) state that charismatic leaders are able to influence their followers' views with regard to a mission/vision and are able to achieve higher levels of commitment to the goals of the group. Most studies investigate charismatic leadership in isolation from their followers and little is known on how the charismatic leader's behavioural interactions with their followers influence follower needs and other behavioural outcomes (Choi, 2006).

\section{Leadership and value congruence in the Men's Sheds}

Value congruence characterises the state of congruence between an individual's values and those of their work environment (Burns, 1978; Jung and Avolio, 2000; Shamir, House and Arthur, 1993). Kristof-Brown, Zimmerman and Johnson (2005) define four ways to conceptualise the congruence theory namely: supplementary congruence, complementary congruence, needs-supplies and demands-abilities perspectives. Supplementary congruence refers to how an organisation and an individual share similar characteristics, such as values (Carless, 2006; Kristof, 1996). Complementary congruence relates to how an organisation and an individual contribute to the fulfilment of each other's needs (Kristof, 1996). The needs-supplies perspective is when an organisation satisfies the needs, desires and/or preferences of an individual (Chan, 1996; Kristof, 1996) and is primarily concerned with meeting individual needs (Cable and DeRue, 2002). In contrast, the demands-abilities perspective suggests that congruence occurs when an individual has the abilities or skills required to meet the demands of the job or the organisation (Chan, 1996). According to Kristof-Brown, Zimmerman and Johnson (2005) this perspective has the least amount of influence on employee attitudes, as it emphasises meeting environmental needs, rather than individual needs. The current study is taken from the supplementary perspective as this study looks at how the similarities between the leader and member values (value congruence) influences the social connectedness of members. From their meta-analyses 
of the literature Kristof-Brown, Zimmerman and Johnson (2005) found that value congruence was most frequently operationalised from the supplementary congruence perspective.

Yukl (2010) proposes that leadership empowers the process of building commitment to an organisation's objectives and inspires followers to accomplish these objectives. Decisions made by leaders, such as Men's Shed co-ordinators, particularly those who are founders of a former organisation, have an effect not only on the direction of the organisation but the direction of its members (Schein, 1992; Schneider, 1987). Schneider et al. (1995) suggest an organisation's goals are in effect an operationalisation of the founder's personality. Thus, leaders, particularly founders, of organisations such as Men's Sheds, embed their personal 'self' and characteristics into organisations by establishing their own objectives of the organisation, which then attracts people who have similar values as the founder (Schneider, 1987).

\section{Leadership, social connectedness and well-being}

Social connectedness is used to describe an aspect of the self that reflects subjective awareness of interpersonal closeness. This sense of closeness is a critical component of one's sense of belonging and is based on the aggregate experiences of proximal and distal relationships. In this respect, social connectedness is an enduring and ubiquitous experience of the self in relation with the world (Lee and Robbins, 2000). McMillan and Chavis’s (1986) framework of social connectedness will be used in this study to investigate how the level of social connectedness is influenced by charismatic leadership and value congruence. The authors define social connectedness as a feeling that members have of belonging, where they matter to one another and where their needs are met through their commitment to each other.

McMillian and Chavis (1986) define four elements of social connectedness. The first element is membership. Membership is the feeling of belonging, feeling of acceptance, or a sense of personal relatedness. Membership includes attributes such as boundaries that identify who belongs and who does not, emotional safety (through belonging), a sense of identification with the group, personal investment and sharing common symbols. The second element is influence. Influence in a community works in two ways: members of a group must feel empowered to have influence over what a group does (otherwise they would not be motivated to participate) whilst group 
cohesiveness depends upon the leader and the group having some influence over its members. The third element is integration and fulfilment of needs. This is the feeling that members' needs will be met by the resources received through their membership in the group. The last element is shared emotional connection. This is the commitment and belief that members have shared and will share history, common places, time together and similar experiences.

Charismatic leaders have the ability to build personal and social identification among their followers which enhance feelings of involvement, cohesiveness and commitment of followers (Shamir, House and Arthur, 1993). Much of the literature investigates the relationships between charismatic leadership and the self-concept and/or social identity of followers (Howell and Shamir, 2005; Kark, Shamir and Chen, 2003; Kirkpatrick and Locke, 1996; Shamir, House and Arthur, 1993; Thomas, Martin and Riggio, 2013). Kark, Shamir and Chen's (2003) study of 76 branch managers and 888 bank employees and Kirkpatrick and Locke's (1996) study of 282 business students, found positive relationships between charismatic leadership and followers' self-efficacy and self-concept. However, there is limited research that explores the relationships between charismatic leadership and social connectedness.

There is evidence to suggest that social connectedness influences the well-being of individuals. Social connectedness provides a personal sense of identity as well as a sense of place in society and is a key feature in identity development and in emotional well-being (Townsend and McWhirter, 2005). Baumeister and Leary (1995) and Cavanagh, McNeil and Bartram (2012) found inextricable links between social connectedness, a sense of belonging, and meaning within larger social and community groups and the well-being of individuals. Furthermore, social connectedness has also been found to have significant relationships with adult participation in community activities and psychological and physical well-being outcomes (Chavis and Wandersman, 1990; Lee, Keough and Sexton, 2002; Lee and Robbins, 2000; Pretty, Conroy, Dugay, Fowler and Williams, 1996). Research has also found that embeddedness in social networks and a sense of community has positively influenced the wellbeing of people (Chipuer, 2001; Morrow, 2000; Pooley, Pike, Drew and Breen, 2002; Whitlock, 2007). This is particularly important and relevant in considering the social and emotional well-being issues of retired men. 


\section{Method}

This study employs a qualitative methodology involving 60 Men's Sheds in urban and regional areas across every state and territory in Australia. Participants include Men’s Shed co-ordinators/leaders and men members. Information was collected by way semi-structured interviews, focus group discussion and observations. Interviews should begin with a list of broad based questions as a guide that generate ease of answers (Lofland and Lofland, 1984). It was considered that the semi-structured interview approach was the most appropriate, as this was the least intrusive method of establishing what co-ordinators know about the Men's Shed environment that helped and/or impeded men's experiences (Lofland, 2006). The focus group method is a form of group interview involving several participants and a facilitator, with a focus on the interaction within the group and joint construction of meaning (Miles and Huberman, 1994). It was important that the researchers listened carefully to what the men had to say and not interfere with the day-to-day routine of those being researched (Lofland and Lofland, 1984). Observations were carried out to enable the researchers to examine situated activity; that is, to gain first-hand insight into the interactions of the men in the Sheds (Lofland, 2006). The qualitative data was analysed using NVivo, following the steps of thematic content analysis outlined by Weber (1985). A coding framework was generated from the literature with independent coding by two researchers to demonstrate the reliability of the coding framework (Carmines and Zeller, 1975).

\section{Participants}

We conducted semi-structured interviews with the co-ordinator/leader of each of the 60 Men's Sheds and focus groups with groups of men who happened to be at the Shed on the day of our visit. In some Sheds there were only three men in attendance and in others there were up to 20. What we found was that if there were 20 men then everyone wanted to be part of what was being discussed an in other groups discussion was with a few men. Hence, from the focus group discussions data were collected from a total of 305 men.

\section{Results}


The data revealed themes relating to the co-ordinators and men's vision for the future, sensitivity to the needs of the men, enhancing skills and capabilities, and the social connectedness that facilitates men’s participation in activities in Men’s Sheds.

\section{Charismatic leadership}

Semi-structured interviews with co-ordinators and leaders of the 60 Men's Sheds aimed to establish if there was any evidence of charismatic leadership in their approach to managing the Sheds. Data revealed different styles of leadership and very distinctive approaches of the leaders/co-ordinators through their influence, emotional connections and fulfilling men's needs.

Leaders/co-ordinators appeared to influence members through their visions for the men and the Sheds:

'To get involved in as many projects as the men request'

'Our Shed generates funds for our own survival...always planning ahead' '...need a new Shed....we'll get the plans together and then ask the Council....they will more than likely fund us'

There was evidence to suggest leaders/co-ordinators establish emotional connections with members:

'We will help as many kids as possible.....we have a program for the next few years'

'We need 'family' in the name of the Shed.....it's about the future'

Leaders/co-ordinators indicated that they fulfilled needs of their members:

'When you have 20 to 30 men on any day then management is critical....it all falls down to you...always looking for best policies and procedures...must have them in place' 'We...run our Shed as safe as we can...want to know the OH\& S [occupational health

and safety] rules'

'Men's Sheds are about getting men skills....we have training courses....men register

for computer courses and welding courses'

'We have 50 financial members and have been holding meetings regularly for the past 3 years...we open in a few months' 
However, there were indications that charismatic leadership was deficient in some Sheds. On one particular visit we were advised on arrival that a regional coordinator would not attend a Shed on that day and unfortunately had not briefed the men to expect visitors. The Shed co-ordinator had not cancelled our visit nor communicated with us. This lack of professional courtesy was not common however we found some co-ordinators did not communicate well and these leaders generated the most apathetic comments and demonstrated the lack of need fulfilment:

'We went broke and no one came to our aid ...when you're in trouble you can't rely on AMSA......but that has to change'

'You jump through hoops [funding applications] and then get nothing.....it's not worth it'

'To write a grant and not get it...it's a killer...it's such a waste of my time...I can't think them any more'

'We're having difficulty with grants....don't know how to complete them' 'We don't really want too many Healthcare Workers in here....reminds the men they're old'

When we held focus groups with men members some gave testimony to the envisioning traits of their co-ordinators. Several of the men in the Sheds expressed their support and gratitude for their leaders/co-ordinators, signalling high levels of emotional connection and membership which can be summed up by a member John:

'Our co-ordinator is more of a facilitator...doesn't tell us what to do.....he listens and really hears what we have to say....he knows where he wants the Shed to be and we're all part of the decision-making'.

Other men were happy to champion their co-ordinators leadership qualities, such as their fulfilment of needs:

'We're learning how to make grandfather clocks....couldn't do it without John' 'Kids who never finished anything in their lives...we help them with every stage of a project until he finished it'

'There's nothing we can't do...just have to ask and someone knows something'

Conversely, in many Sheds there was reticence towards any kind of leadership that reminded men of their previous workplaces where they had experienced autocratic leadership. The men's vision of a Shed and their continued support for their co- 
ordinator had a caveat and that meant the future of their support for the Shed was dependent upon protecting them from workplace memories.

Some leaders were seen to negatively influence as a result of top-down leadership style and bureaucratic principles:

'We don't want anyone to tell us how to run the Shed.....

'We don't want bureaucracy....we got away from that when we left the workforce'

'We want to choose our own destiny here'

'The hierarchy needs to let us decide what we need rather than try and tell / give us something we don't need'

'The last thing we want is to be led down some dark road that'll lead to bureaucracy'

'We want to stay de-centralised'

'Men's sheds should not be regulated, stamped or bureaucratized'

'We keep talking about projects.....not into them yet'

Some members found that leaders did not create a sense of belonging and membership in the Sheds:

'Our co-ordinator just left....all he did was look after himself....played cards on the computer all day'

'Kevin [Shed co-ordinator] isn't here today....we make things....organise events but no-one comes'

'Basically we rely on blow ins.....there's no social invitation.....if they come, they come'

'Our co-ordinator's not community minded'

'We would never ask anyone to come here [to the Shed] because they mightn't be welcome [by the co-ordinator]'

\section{Charismatic leadership and Social connectedness}

There were several Sheds where we found charismatic leaders who aim to enhance the social connectedness of men members. One way Shed co-ordinators worked to enhance social connectedness was to genuinely display empathy to the difficulties that some men face on their transition from work to retirement. There was 
also a general consensus amongst many co-ordinators when we asked them to reflect on the kinds of difficulties that many individuals [men, women children] experience.

Leaders/co-ordinators expressed how they establish an emotional connection:

'Our Shed is our new home.... a place for isolated men to have somewhere to go'

'Most 'bad' kids are dysfunctional in care....here we care'

Leaders/co-ordinators fulfilled the needs of members:

'When a man leaves work he doesn't have anywhere to go....the Shed fills that void'

'We had a Mental Health Project.....some men with mental health issues came and worked on a mosaic for ten weeks...if we run ten week blocks they work really well'

'Some kids at school are a huge problem....here they are model children....we will help as many as possible'

'Encourage young people like the school kid who comes here once a week....we're helping him build a jazz base guitar'

One story that emphasises a high level of empathy and membership was told by a leader named Jack:

'Our oldest member is 97 and he has a 62 year old son....both previous recluses. They've lived in the area for more than 30 years and neither have had any involvement whatsoever in the community. Now come on the dot of 9am they come in [to the Shed] and play pool. Harry [97 year old] is the cashier for the day at Mitre 10 store when we have a BBQ.....first time he's done something other than play pool. You couldn't dampen his enthusiasm. Harry doesn't have much time left before he'll pass away, so he's introduced his son to a network that will carry him through the inevitable grief and aftermath of Harry's passing. George will be able to step out from under his father's shadow and we'll look after him'.

On the other hand, there were co-ordinators who set the parameters of membership to exclude others in need: 
'We don't want kids and definitely no women with their problems here'

'Our Shed is not a baby-sitting service'

'We don't allow men with disabilities....in this Shed....too much responsibility'

'To involve women would be a fatal kiss'

'We're a small groups [6 members] not racist against one race. We hate everyone'

'Don't want kids here...other Sheds do but we don't want the responsibility' The comments here demonstrate negative aspects of membership through dis-inclusion and discrimination.

During the focus groups men discussed the management systems in the Sheds and the role of their leaders/co-ordinators and how they were empathetic to their needs. The data revealed two different kinds of reaction to our guiding questions about how their leader catered to the needs of men members. The following represents what men understand to support their needs.

The men explained the ways in which leaders/co-ordinators provide support and a sense of identity and membership:

'We've got good systems here......the co-ordinators really look after us and make sure we stick to the rules'

'We all work together... we share information...always communication here' 'A young guy came in to play darts...watched us building a timber boat ....we got him involved and now he works for a boat building company'

'Not one kid has been banned from the Shed....they can't go to school but James [Shed co-ordinator] let's them come here'

Men also voiced in what manner their leaders/co-ordinators fulfilled the needs of men members:

'I attend three different Men's Sheds each week. At each of the Sheds the management is the same....good fella who manages the place..... fits the needs of the blokes'

'He goes to the schools and we help kids in trouble' Leaders provide positive influence on youths:

'The mother of a young kid [aged 16] came in and asked how we could help.....the kid came here for 6 months...changed his life....he's now an apprentice carpenter' 
'A lady came to the Shed about her rebellious kid.....we all wanted to help....she needed help too....kid's sorted out and she still comes every day and helps out ....makes the best scones'

When reflecting on their experiences with the leader/co-ordinator some men members revealed problematic patterns of leadership behaviour. The men told us that leaders/co-ordinators sometimes lack influence and the skills to manage the Shed's:

'We make things but when we organise open days no-one comes.....Joe [coordinator] says we shouldn't have to advertise....people should just come' 'Our application for funding was unsuccessful.....don't have anyone here who knows how.....we don't ask for any help'

'What we do is limited by money....it's always money.....not sure what the problem is'

'We need to better provide access to health services....if we ask it might happen' 'Our co-ordinator won't allow computers here.....emailing is a self-generating trap'

\section{Social connectedness and well-being}

Through the planning, organising and leading efforts of many Shed coordinators there was much evidence of charismatic leadership through the empowerment of men members through stories about training and skill development which led to men revealing positive feelings of well-being such as a sense of satisfaction and heightened self-esteem.

Leaders/co-ordinators fulfil needs through social connectedness:

'Give men the skills they can do anything'

'When we finish a project we're all proud....can't take the smiles off the men's faces'

'We restore old motor bikes....when the men get something working...they go wow....such a sense of satisfaction'

Leaders/co-ordinators talked about their influence [on men members] through sharing their own skills and abilities:

'Providing my expertise in woodwork, leadlight, French polishing and any other area to get the men through'

'When you get men together....they can be tough on each other....quite brutal in 
fact....but they love it....give each other heaps.....that's what men like to do...they learn new skills.....work hard....gives them something to do and feel proud'

Those Shed leaders/co-ordinators who gave the impression they are deficient in charismatic leadership skills told stories that highlighted a lack of influence and commitment:

'If we had the resources we could make things and then sell them....it would be good to know you made something that would sell'

'Don't do any community work.....men sit around and have coffee.....we got a shed full of tools but only use them when the men feel like it'

During the focus groups men members reflected on the skills that enabled them and others to achieve something they may once have thought was out of their reach. Leaders appeared to have a positive influence on the learning and behavioural outcomes of their members:

'Our co-ordinator was a chef in another life...he's happy to share his skills with us'

'We're learning how to make grandfather clocks....without John we would never have had that opportunity'

'In the Shed I have to think about things...it keeps me young.....improves the memory....I feel inspired to take on a project'

'We work with Scouts and Cubs.... ${ }^{\text {th }}$ Day Adventist kids ....get them to make possum boxes....environmentally friendly....it's good for them to make things that make a difference.....they start to understand what the environment is all about'

'Our Shed has a 'no smoking or alcohol' project because a lot of the problems men suffer are related to these substances....men get back on track'

Men members also articulated how leaders/co-ordinators help to fulfil needs [of men members] by cultivating practical skills and abilities:

'We do upholstery here....the wife was real happy 'cause I've fixed the lounge' 'Look at the pride in kids eyes.....he'll always know he planned it with the men in the Shed and they helped him complete a project' 
Many of the men revealed how there were difficulties related to getting involved in projects. Some of the men's comments demonstrate their feelings of disempowerment through leaders/co-ordinators not fulfilling their needs:

'Men need something to achieve in their lives....if we don't have projects we don't feel like we achieved anything'

'We sit around and talk....it would be really good if we had the resources to make things'

'We don't have a newsletter so we don't get to tell anyone what we don't do...'cause we don't do much'

Overall, it was the leader's ability to involve, facilitate and develop emotional connections with their members that contributed to the positive feelings of belongingness and well-being of the men members.

\section{Discussion}

This study highlights the importance of leadership in Men's Sheds and the impact on men's participation and levels of social connectedness. Our study suggests that Men's Sheds can facilitate a healthy transition from work to retired life for many men if the particular facility has effective leadership. Leaders play an important role in shaping the way men think about and react to practices in the Shed. Effective leaders encourage men to engage in group activities and by doing so they form friendships and talk about their health and other social issues. Men members enjoyed the informal atmosphere of the Shed, where leaders were supportive and empathetic to the men members. To many members it was this type of leadership that distinguished the leadership roles in the Men's Shed to other traditional work organisations. Corresponding to these perceptions authors contend that men who have good experiences will help to enhance the overall effectiveness, cohesiveness and commitment of the group (Bass, 1985; Burns, 1978; Feinberg, Ostroff and Burke, 2005; Korek, Felfe and Zaepernick-Rothe, 2010; Poppa and Zakkai, 1994; Shamir, 1995). We argue that charismatic leadership and clearly articulated management practices may be an important vessel to establish social connectedness and sense of belonging amongst members. 
We identified co-ordinators who surpass the model of envisioning, empathy and empowerment. In these Sheds the co-ordinators had a clear vision for the future; most of these leaders talked about the future growth and sustainability of the Shed. Shed coordinators exhibiting charismatic elements of empathy were found to have the strongest impact on the social connectedness factors, membership, influence and fulfilment of needs. This corresponds to Choi (2006) who suggests that charismatic leaders have the propensity to demonstrate emotions and sensitivity to their follower's needs. These kinds of co-ordinators have an impact that extends beyond the Shed, for example when men are involved in activities that enable them to fix things at home and impress their wives/partner or family. Their involvement in the Shed not only gave men a sense of ownership and empowerment but also helped improve family and community relations. In these Sheds the leaders had a clear vision for the men that resulted in individual and Shed [group] empowerment.

Leaders exhibiting charismatic elements of envisioning were related to social connectedness factors of membership, influence and fulfilment of needs. Leaders who displayed charismatic elements of envisioning worked collaboratively with members to positively influence and develop emotional connections. These leaders also focused on supporting and fulfilling needs, such as training, occupational health and safety and general well-being. It was evident that some of the leaders did not have the skills and knowledge required to effectively manage the operations of the Shed, which negatively impacted the sense of belonging to the group resulting in some members feeling that their needs were not being satisfied.

Charismatic leaders are particularly skillful in communicating their ideas and their ability to engage and persuade through personal appeals (Conger, 1989). However, there were obvious communication issues in some of the Sheds, alluding to the need for better leadership skills and charismatic ability. The fact that men were not advised about the objectives of the leader's visit to one Shed indicates a possible emotional disconnect between the leader and the members.

Leaders exhibiting charismatic elements of empowerment were found to have the strongest impact on the social connectedness factors, membership and fulfilment of needs. Leaders, who demonstrated charismatic elements of empowerment used their skills and expertise to encourage the men, enable them to learn new skills and give them a sense of pride. Men members felt empowered and inspired by their leaders, were 
proud of their achievements, experienced a sense of satisfaction and believed that they were making a difference. Correspondingly, Choi (2006) suggests that charismatic leaders allow followers to feel influential and competent. Some men felt that the limited resources and sometimes lack of direction did have a negative impact on their emotional needs. Thus, signaling the importance of charismatic leadership being used to enhance the social connectedness in the Men's Shed.

The findings also show that members value flexibility in the practices employed and the decision's made in the Mens Sheds, whereby charismatic and participative styles of leadership are preferred, in comparison with how some men perceived their traditional organisational workplaces where little flexibility and involvement occurred. Members talked about not being involved in decision making in their pre-retirement jobs and how effective leaders in the Men's Sheds had changed this experience for them by being inclusive. Men not only valued a high level of inclusion, but also the supportive and empathic nature of leaders in the Sheds who disploayed these charismatic leadership attributes. Leaders who involved members in the decisionmaking process, made them feel included and their ideas valued. To many members it was this type of leadership that distinguished the leadership roles in the Men's Shed to other traditional work organisations.

Members also identified how management practices helped facilitate their ability to learn new skills and how effective leadership adds identity and significance to the tasks they perform at the Men's Sheds. Clearly, the leadership role of the co-ordinator is important in supporting the men and providing an environment within which men are appreciated and respected. Thus, charismatic leadership is particularly important in the Sheds due to how they build feelings of involvement, cohesiveness and commitment in the group (Bass, 1985; Burns, 1978; Feinberg, Ostroff and Burke, 2005; Korek, Felfe and Zaepernick-Rothe, 2010; Poppa and Zakkai, 1994; Shamir, 1995).

The relationship between charismatic leadership and social connectedness was also found to positively influence the well-being of the men members. When charismatic leadership was present in the shed, members felt proud and happy. Members felt that they could achieve more and experienced a heightened sense of satisfaction. Conversely, where charismatic leadership was not present, members felt disengaged and dissatisfied and demonstrated definite signs of low social and emotional well-being. These findings have implications for men's groups under effective 
leadership to address the factors that negatively influence many men's lives (e.g. depression), and maximise the opportunity for better health and social well-being opportunities for men and their families. The findings may also be of interest to other countries, government departments, healthcare workers and researchers. Overall, this study has found that charismatic leadership, value congruence and social connectedness contribute to the social and emotional well-being of men. Limitations exist as this study used qualitative data and was limited in the number of participants selected to offer their views. Future research of a quantitative nature would be beneficial to further validate the findings in this study. 


\section{References}

Arney, F., and Westby, M. (2012a), "Men's places literature reveiw." Darwin, NT: Child Protection Research Program, Menzies School of Health Research.

Arney, F., and Westby, M. (2012b), "Mens places literature reveiw." Darwin, NT: Child Protection Research Program, Menzies School of Health Research.

Australian Bureau of Statistics. (2011), "Australian Social Trends." Canberra: Australian Bureau of Statistics

Australian Men's Shed Association. (2011), "www.mensshed.org."

Ballinger, M., Talbot, L., and Verrinder, G. (2009), "More than a place to do woodwork: A case study of a community-based men's shed." Journal of Men's Health Vol. 6 No. 1, pp. 20-27.

Ballinger, M.L., Lyn, A., Talbot, L.A., and Verrinder, G.K. (2009), "More than a place to do woodwork: a case study of a community-based Men's Shed." Journal of Men's Health Vol. 6 No. 120-27, pp.

Bandura, A. (1977), "Self-efficacy: Toward a unifying theory of behavioral change." Psychological Review Vol. 84 No. 2, pp. 191-215.

Bass, B.M. (1985), Leadership and performance beyond expectations. New York: Free Press.

Baumeister, R.F., and Leary, M.R. (1995), "The need to belong: Desire for interpersonal attachment as a fundamental human motivation." Psychological Bulletin Vol. 117 No. pp. 497-529.

Boehm, A., and Yoels, N. (2009), "Effectiveness of welfare organizations: The contribution of leadership styles, staff cohesion and worker empowerment." British Journal of Social Work Vol. 39 No. pp. 360-1380.

Brown, M.E., and Trevino, L.K. (2009), "Leader-follower values congruence: Are socialized charismatic leaders bettwe able to achieve it?" Journal of Applied Psychology Vol. 94 No. 2, pp. 478-90.

Bryman, A., Stephens, M., and Campo, C. (1996), "The importance of context: qualitative research and the study of leadership." Leadership Quarterly Vol. 7 No. 3, pp. 353-70.

Burke, W.W. (1986), "Leadership as empowering others." Pp. 51-77 in Executive power, edited by S Srivasta. San Francisco, CA: Jossey-Bass.

Burns, J.M. (1978), Leadership. New York: Harper \& Row.

Cable, D.M., and DeRue, D.S. (2002), "The convergent and discriminant validity of subjective fit perceptions." Journal of Applied Psychology Vol. 87 No. 8, pp. 875-84.

Carless, D. (2006), "Differing perceptions in the feedback process." Studies in Higher Education Vol. 31 No. 2, pp. 219-33.

Carmines, E.G., and Zeller, R.A. (1975), Reliability and validity assessment. California: Sage Publications.

Cavanagh, J., McNeil, N., and Bartram, T. (2012), "The Australian mens shed movement: Human resource management in a voluntary organisation " Asia Pacific Journal of Human Resources Vol. 51 No. 3, pp. 292-306.

Cavanagh, J., McNeil, N., Bartram, T., and Leggat, S. (2012), "An exploratory study of the factors that promote Indigenous and non-Indigenous member's participation in Men's Sheds." Journal of Australian Indigenous Issues Vol. 15 No. 1, pp. 5064. 
Chan, D. (1996), "Cognitive misfit of problem solving style at work: A facet of personorganization fit." Organizational Behavior and Human Decision Processes Vol. 68 No. 3, pp. 194-207.

Chavis, D.M., and Wandersman, A. (1990), "Sense of community in the urban ennvironment: A catalyst for participation and community development." American Journal of Community Psychology Vol. 18 No. pp. 55-81.

Chipuer, H.M. (2001), "Dyadic attachments and community connectedness: Links with youths’ loneliness experiences." Journal of Community Psychology Vol. 29 No. 4, pp. 429-46.

Choi, J. (2006), "A Motivational Theory of Charismatic Leadership: Envisioning, Empathy, and Empowerment." Journal of Leadership and Organizational Studies Vol. 13 No. 1, pp. 24-43.

Conger, J.A. (1989), The charismatic leader: Behine the mystique of exceptional leadership. San Francisco, CA: Jossey-Bass.

Conger, J.A., and Kanungo, R.N. (1988), "The empowerment process: integrating theory and practice " Academy of Management Review Vol. 13 No. 3, pp. 47182.

Conger, J.A., and Kanungo, R.N. (1998), Charismatic leadership in organizations. Thousand Oaks, CA: Sage.

Conger, J.A., Kanungo, R.N., and Menon, S.T. (2000), "Charismatic leadership and follower effects " Journal of Organisational Behaviour Vol. 21 No. 7, pp. 74767.

Feinberg, B.J., Ostroff, C., and Burke, W.W. (2005), "The role of within-group agreement in understanding transformational leadership." Journal of Occupational and Organizational Psychology Vol. 78 No. pp. 471.

Glover, C., and Brown, E. (2006), "Written feedback for students: Too much, too detailed or too incomprehensible to be effective?" Bioscience education $e$ journal Vol. 7 No. pp. 7-22.

Golding, B. (2008), "Researching Men's Sheds in Community Contexts in Australia: What Does It Suggest about Adult Education for Older Men? ." Journal of Adult and Continuing Education Vol. 14 No. pp. 17-33.

Golding, B. (2011), "Social, local, and situated: Recent findings about the effectiveness of older mens informal learning in community contexts." Adult Education Quarterly Vol. 61 No. 2, pp. 103-20.

Golub, S.A., Filipowicz, A., and Langer, E.J. (2002), "Acting your age." Pp. 277-94 in Ageism: Stereotyping and prejudice against older persons, edited by T.D Nelson. Cambridge, MA: MIT Press.

Guay, R.P. (2013), "The relationship between leader fit and transformational leadership." Journal of Managerial Psychology Vol. 28 No. 1, pp. 55-73.

Hoffman, B.J., Bynum, B.H., and Piccolo, R.F. (2011), "Person-organization value congruence: How transformational leaders influence work group effectiveness." Academy of Management Journal Vol. 54 No. 4, pp. 779-96.

Hogan, R., Curphy, G.J., and Hogan, J. (1994), "What we know about leadership: Effectiveness and personality." American Psychologist Vol. 49 No. 6, pp. 493504.

Hollander, E.P. (1993), "Legitimacy, power, and influence: a perspective on relational features of leadership." Pp. 29-47 in Leadership theory and research:

Perspectives and directions, edited by M.M Chemers and R Ayman. California: Academic Press. 
House, R.J., and Shamir, B. (1993), "Toward the integration of transformational, charismatic, and visionary theories." Pp. 81-107 in Leadership theory and research: Perspectives and directions, edited by M.M \& Chemers and R Ayman. California: Academic Press.

Howell, J.M., and Shamir, B. (2005), "The role of followers in the charismatic leadership process: relationships and their consequences." Academy of Management Review Vol. 30 No. pp. 96-112.

Huang, M., Bor-Shiuan, C., and Chou, L. (2005), "Fitting in organizational values: The mediating role of person-organization fit between CEO charismatic leadership and employee outcomes." International Journal of Manpower Vol. 26 No. 1, pp. 35.

Jung, D.I., and Avolio, B.J. (2000), "Opening the black box: an experimental investigation of the mediating effects of trust and value congruence on transformational and transactional leadership." Journal of Organizational Behaviour Vol. 21 No. pp. 949-64.

Kark, R., Shamir, B., and Chen, G. (2003), "The two faces of transformational leadership: Empowerment and dependency." Journal of Applied Psychology Vol. 88 No. 2, pp. 246-55.

Kirkpatrick, S.A., and Locke, E.A. (1996), "Direct and Indirect Effects of Three Core Charismatic Leadership Components on Performance and Attitudes." Journal of Applied Psychology Vol. 81 No. 1, pp. 36-51.

Klein, K., and House, R.J. (1995), "On fire: charismatic leadership and levels of analysis." Leadership Quarterly Vol. 6 No. pp. 183-98.

Korek, S., Felfe, J., and Zaepernick-Rothe, U. (2010), "Transformational leadership and commitment: A multilevel analysis of group-level influences and mediating processes." European Journal of Work and Organizational Psychology Vol. 19 No. 3, pp. 364-87.

Kristof-Brown, A.L., Zimmerman, R.D., and Johnson, E.C. (2005), "Consequences of individuals' fit at work: A meta-analysis of person-job, person-organization, person-group, and person-supervisor fit." Personnel Psychology Vol. 58 No. 2, pp. 281-342.

Kristof, A. (1996), "Person-organization fit: an integrative review of its conceptualizations, measurement and implications." Personnel Psychology Vol. 49 No. 1, pp. 1-49.

Labonte, R., and Reid, E. (1997), "Participation and Partnerships for Health Promotion." Carlton: Victoria Health.

Lee, R.M., Keough, K.A., and Sexton, J.D. (2002), "Social connectedness, social appraisal, and perceived stress in college women and men." Journal of Counseling and Development Vol. 80 No. pp. 355-61.

Lee, R.M., and Robbins, S.B. (2000), "Understanding social connectedness in college women and men." Journal of Counseling and Development Vol. 78 No. pp. 484-91.

Lofland, J. (2006), Analyzing social settings: A guide to qualitative observation and analysis. Belmont, CA: Wadsworth/Thomson Learning.

Lofland, J., and Lofland, L.H. (1984), A guide to qualitative observation and analysis. Belmont, California: Wadsworth Publishing Company.

Lord, R.G., Brown, D.J., Harvey, J.L., and Hall, R.J. (2001), "Contextual constraints on prototype generation and their multilevel consequences for leadership perceptions." Leadership Quarterly Vol. 12 No. 3, pp. 311-38. 
Lyons, M., Hocking, S., Hems, L., and Salamon, L.M. (1999), "Australia." Pp. 203-17 in Global civil society: Dimensions of the nonprofit sector, edited by L.M Salamon, H.K Anheier, R List, S Toepler, and S.W Sokolowski. United States: The Johns Hopkins Center for Civil Society Studies.

McMillan, D.W., and Chavis, D.M. (1986), "Sense of community: A definition and theory." Journal of Community Psychology Vol. 14 No. 1, pp. 6-23.

McMurray, A.J., Pirola-Merlo, A., Sarros, J.C., and Islam, M.M. (2010), "Leadership, climate, psychological capital, commitment, and wellbeing in a non-profit organization." Leadership \& Organization Development Journal Vol. 31 No. 5, pp. 436-57.

Miles, M., and Huberman, A. (1994), Qualitative data analysis: An expanded source book. Thousand Oaks: Sage.

Misan, G. (2008), "Men’s Sheds - a strategy to improve men’s health." Spencer Gulf Rural Health School (SGRHS), The University of Adelaide and the University of South Australia and Centre for Rural Health and Community Development (CRHaCD), University of South Australia.

Misan, G., and Sergeant, P. (2009), "Men's sheds: A strategy to improve men's health." in 10th National Rural Health Conference. Cairns, Queensland.

Morgan, M., Hayes, R., Williamson, M., and Ford, C. (2007), "Men's Sheds: A community approach to promoting mental health and well-being." International Journal of Mental Health Promotion Vol. 9 No. 3, pp. 48-52.

Morrow, V. (2000), "'Dirty looks' and 'trampy places' in young people's accounts of community and neighborhood: Implications for health inequalities." Critical Public Health Vol. 10 No. 2, pp. 141-52.

Ormsby, J., Stanley, S, Jaworski, K. (2010), "Older men’s participation in communitybased men's sheds programmes." Health and Social Care in the Community Vol. 18 No. 6, pp. 607-13.

Pooley, J.A., Pike, L.T., Drew, N.M., and Breen, L. (2002), "Inferring Australian children's sense of community: A critical exploration." Community, Work \& Family Vol. 5 No. 1, pp. 5-22.

Poppa, M., and Zakkai, E. (1994), "Transactional, charismatic and transformational leadership: Conditions conducive to their predominance." Leadership and Organization Development Journal Vol. 15 No. 6, pp. 3-7.

Pretty, G.M.H., Conroy, C., Dugay, J., Fowler, K., and Williams, D. (1996), "Sense of community and its relevance to adolescents of all ages." Journal of Community Psychology Vol. 24 No. 4, pp. 365-79.

Schein, E.H. (1992), Organizational culture and leadership. San Francisco: JosseyBass.

Schneider, B. (1987), "The people make the place." Personnel Psychology Vol. 40 No. pp. 437-54.

Schneider, B., Goldstein, H.W., and Smith, D.B. (1995), "The ASA framework: An update." Personnel Psychology Vol. 48 No. 4, pp. 747-73.

Shamir, B. (1995), "Social distance and charisma: Theoretical notes and an exploratory study." Leadership Quarterly Vol. 6 No. 1, pp. 19-47.

Shamir, B., House, R.J., and Arthur, M.B. (1993), "The motivational effects of charismatic leadership: A self-concept based theory." Organizational Science Vol. 4 No. 4, pp. 577-94. 
Thach, E., and Thompson, K.J. (2007), "Trading places: Examining leadership competencies between for-profit vs. public and non-profit leaders." Leadership \& Organization Development Journal Vol. 28 No. 4, pp. 356-75.

Thomas, G., Martin, R., and Riggio, R.E. (2013), "Leading groups: Leadership as a group process." Group Processes and Intergroup Relations Vol. 16 No. 1, pp. 316.

Thomson, M. (2002), The complete blokes and sheds: stories from the sheds. Sydney: Harper Collins.

Townsend, K.C., and McWhirter, B.T. (2005), "Connectedness: A review of the literature with implications for counseling, assessment and research." Journal of Couseling and Development Vol. 83 No. 2, pp. 191-201.

Weber, R.P. (1985), Basic content analysis Beverly Hills CA: Sage.

Whitlock, J. (2007), "The role of adults, public space, and power in adolescent community connectedness." Journal of Community Psychology Vol. 35 No. 4, pp. 499-518.

Yukl, G. (2010), Leadership in organizations. New Jersey: Prentice Hall. 